\title{
Towards a balancing act between the emergence of prophetic churches and organisational culture in South African Pentecostalism
}

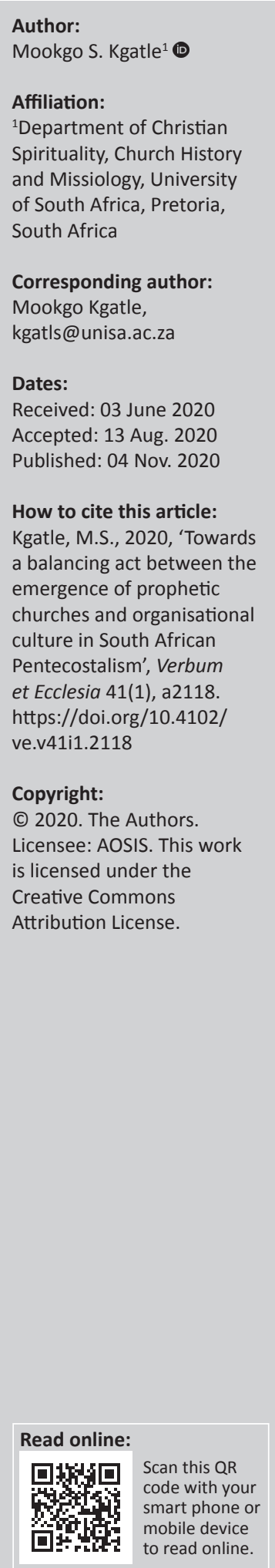

Scholars with interest in South African Pentecostalism have highlighted the emergence of New Prophetic Churches (later NPCs) in South Africa in the last 5 years. These scholars have indeed characterised NPCs, their theology of new prophetism and pointed to the leading figures in these churches. Majority of these scholarly works have highlighted the abuse of religion by some NPCs. Research gap exists in the relationship between the NPCs and organisational culture. Scrutiny at these churches demonstrates that they encapsulate anti-organisation and anti-structure ideals that soon or later may hinder their growth. Therefore, the main contribution of the article is to seek ways in which NPCs can find balance between their emergence and organisational culture. This will be achieved by highlighting through literary analysis and observation some disadvantages that can impede the growth of these churches. In addition, the article suggests a balanced act in ecclesiological framework that will ensure the sustainability of the emergence of NPCs in South Africa.

Interdisciplinary and/or interdisciplinary implications: This article is an interdisciplinary study between missiology and practical theology. The article suggests the balancing act in ecclesiology between NPCs and organisational culture in order to deal with the challenges of anti-organisational culture within South African Pentecostalism.

Keywords: Pentecostalism; New Prophetic Churches; institutionalism; prophets; theology; ecclesiology.

\section{Introduction}

There is no doubt that Pentecostalism from its beginning has rejected a form of organisational culture. Hence, Pentecostalism began as a movement rather than an established church. The Pentecostal movement in Azusa Street Revival led by an African-American preacher, William Seymour illustrates this. In Azusa Street, people from across the globe gathered in one street to worship and fellowship. The revival lasted for more than 8 years. At this point, there was no formal structure where people could affiliate; it was more of a movement. Azusa Street Revival is also a product of movements like the holiness movement. The same way when John G Lake and Thomas Hezmalhach came to South Africa in 1908, they did not have an idea of starting a church or of having a formal structure but rather were inspired by the Azusa Street Revival and wanted to maintain the same move of God in Bree Street Johannesburg. History shows that when the Apostolic Faith Mission (AFM) started by John G Lake was institutionalised, the church moved towards schisms and divisions. ${ }^{1}$ This might be a motivation amongst many New Prophetic Churches (later NPCs) to move away from organisational culture. However, the lack of organisational culture contributes to lack of accountability, lack of financial stewardship, lack of clear vision and lack of stability. This article explains the link between organisational culture and NPCs in South Africa. This will be achieved by looking at the tendencies of anti-organisational culture in these churches. The article engages these anti-organisational culture tendencies and recommends the way forward through ecclesiological theoretical framework.

\section{Organisational culture within ecclesiological theoretical framework}

Ecclesiology is the study of the organisation of the church with the integration of the doctrine and belief systems of a specific church (Fahlgren \& Idestrom 2016:106). This article discusses 1.The AFM in its early stages was strong on revivals but with the departure of John G Lake, the church became organised according to the
racial divisions that existed during apartheid in South Africa, black, white, mixed race and Indian (see Kgatle 2017). This set up alienated many black pastors and led to various schisms in the church (Kgatle 2016) 
organisational culture within the ecclesiological theoretical framework. The creation of an organisational culture (Connors \& Smith 2011:1) allows people to 'embrace accountability toward one another and toward the organization'. This is important for the success and sustainability of organisations. On the other hand, lack of organisational culture results in confused visions, structure and other strategic processes in the church (Boshart 2010:XVI). In this article, the lack of organisational culture produces lack of accountability, lack of financial stewardship, lack of clear vision and lack of stability. This article will illustrate through an ecclesiological framework that NPCs embrace lack of organisational culture and the disadvantages thereof. The article also illustrates the ways on how NPCs can move towards a balance act in ecclesiology.

\section{Methodology}

The first method used in this article is literary analysis. The article will rely on the publications that have been published on NPCs within the southern African region. The advantage is that the NPCs are studied within the broader South African Pentecostalism whereby enormous research has already been done by many scholars. Therefore, a literary analysis on NPCs will be juxtaposed with the existing literature on South African and global Pentecostalism. The second method is observation method as the author can be considered as both an insider (of Pentecostal tradition) and an outsider (having conducted research amongst Pentecostals) but very focused in the objectivity of their research. Thus, in discussing organisational culture within NPCs, the author will be as objective as possible.

\section{Organisational culture and Pentecostalism}

Since its beginning, Pentecostalism has shied away from organisational culture and embraced the hermeneutics of experience that is based on the work of the Holy Spirit (Kärkkäinen 2007:6). In striving to release the Spirit from organisational culture and excessive theological formulae and fundamentalistic pedagogy, Pentecostals tend to trap the Spirit in experiential criteria (Kärkkäinen 2007:6). Pentecostalism even in its infancy was opposed to a form of organisational culture of the denominational churches. According to Resane (2017:3), 'The spirit of antiinstitutionalism that dominated American Christianity in the sixties enhanced and expedited the growth of the charismatics worldwide'. There is no doubt that anti-organisational tendencies had always been a hallmark of the Pentecostal and charismatic ecclesiology since its embryonic egression. Spirituality in Pentecostalism according to Jaichandran and Madhav (2003:49) is identified with the individual relationship with God as well as with the questioning of organisational culture. As a result, the contemporary breakdown of traditional values and communal life is compensated for by a renewal of spirituality. Pentecostal movements like the holiness movement and the Apostolic Faith Movement illustrate this anti-organisational culture.
In South Africa, whilst classical Pentecostal denomination like the AFM, Assemblies of God and the Full Gospel church have clearly defined an organisational culture, the NPCs have not done so. The anti-organisational culture exists amongst NPCs as they are embedded in movements rather than established denominations. Thus, the description of anti-organisational culture suits NPCs very well as they are opposed and very much critical to a formal structure that is common in old and denominational churches. Neo-Pentecostals like NPCs view and identify themselves in contrast to the establishment of a formal structure; hence, they always view themselves as a movement. This is what distinguishes neo-Pentecostalism like NPCs from other Pentecostals, especially that of established categories (see Vondey 2012:59). However, it is important to point out that it is not all neo-Pentecostals that are anti-organisational structure. Some leading African neo-Pentecostal churches, such as Bishop Musa Sono's Grace Bible Church, have become denominational and therefore institutionalised. Furthermore, the institutional model in many classical Pentecostals is informed with other-worldliness whilst the institutional model in neo-Pentecostalism focuses on thisworldliness. Therefore, a discussion on organisational culture within South African Pentecostalism should avoid generalisations. To avoid such generalisations, this article focuses on the NPCs discussed below.

\section{New Prophetic Churches in South Africa}

Scholars interested in South African Pentecostalism have come up to highlight the emergence of NPCs. These works discuss NPCs as part of South African Pentecostalism but different from other three streams or sub-traditions outlined by Anderson (1992; cf Kgatle 2020:3; Mashau 2013:12) like Pentecostal Charismatic Churches (PCC) (Anderson 2002:167) or classical Pentecostalism (Anderson 2004:105, 2013; Frahm-Arp 2010:153; Kalu 2008:55; Kay 2011:45; Nel 2019), African Independent Pentecostal Churches (AIPC) (Anderson 2005:66) and Charismatic Churches (Anderson 2005:70). The reason for classifying them as Pentecostals is that many of them have maintained the fundamental teachings of Pentecostalism like the baptism of the Holy Spirit with the evidence of speaking in other tongues. These churches exist elsewhere, in Zimbabwe, Chitando and Biri (2016), call them the Pentecostal prophetic sector. They are also prominent in West Africa in countries like Ghana (see Omenyo \& Arthur 2013; Quayesi-Amakye 2015).

What seems to be the main distinction is that many of these churches are more inclined to the prophetic tradition. According to Kgatle (2019a), these churches are known for four reasons: firstly, they practice what most of their leaders call forensic prophecy or one-on-one prophecy where believers receive direct prophecy that involves their daily living including personal information like cell phone number, car registration number and so forth. Secondly, their deliverance ministry unlike on other streams is based on consultations where they charge around R7000.00 or more 
per consultation. Thus, members can consult a prophet to receive counselling or direction for their lives, but they will need to pay a certain fee depending on the level of their problems (Tsekpoe 2019:280). Thirdly, one of the common miracles that they perform whilst ministering on the podium is 'miracle money' that appear in people's accounts without working for it (cf Vengeyi 2014:29). Lastly, they are known for their love of prophetic titles like 'major 1 ' or 'seer 1' 'Mzansi prophet' and other fashionable prophetic titles (Kgatle 2019b:4; cf Banda 2020:1). These are churches like the Enlightened Christian Gathering (ECG) of Prophet Shepherd Bushiri in Pretoria (Ramantswana 2019:3), Alleluia ministries of Pastor Alph Lukau in Sandton, Rabonni Ministries of Pastor Daniel Lesego in Soshanguve and Incredible Happenings of Pastor Paseka Motsoeneng (Dube 2020:42)

\section{Anti-organisational culture in New Prophetic Churches in South Africa}

As indicated in the Methodology section, there is a close link between Pentecostalism and anti-organisational culture. Pentecostal movements in South Africa are radical as opposed to other established missional denominations. As highlighted in previous sections, it is because of their emphasis on the work of the Holy Spirit. Thus, the Pentecostal movement is a direct reaction to reserved ecclesiology in denominations like the Roman Catholic Church, the Anglican Church, the Presbyterian Church and the Dutch Reformed Church. The NPCs in South Africa have adopted the same tendency of anti-organisational culture that operated in the dispensation of early Pentecostal movements. The experiences of spiritual encounter of visions, revelations, signs and wonders, and other manifestations of the Spirit's presence and power were the source and the impetus for the Pentecostal missiology in which the early Pentecostals were engaged; and NPCs are engaged today. This being the case, however, there are fundamental differences in how these visions and manifestations are experienced; the early Pentecostals had genuine experiences, whereas some NPC prophets fake such experiences. These emerging churches regard themselves as non-denominational as they have no link with the denominational churches like AFM, Assemblies of God and Full Gospel. They do so to maintain their independence and lack of accountability. They are in most cases, antidenominational, and refuse endorsement of them. Scrutiny reveals that they encapsulate anti-organisation and antistructure ideals. These anti-organisational culture tendencies according to Resane (2017:5) have caused these churches to engage in outrageous acts like the eating of snakes and dog meat, drinking of petrol, taking selfies in heaven, spraying of Doom, walking on air, body walking, body resurrecting and others. Furthermore, NPCs' anti-organisational culture is seen in the claims to carry a unique anointing by many of the prophets, the man of God syndrome and manipulation of scripture. These tendencies are discussed in detail in the following section.

\section{A critical reflection on the spirit of anti-organisational culture Lack of accountability}

The leaders in NPCs reject a form of accountability. The men and women of God in NPCs perceive themselves as prophets who hear from God and therefore they should not be questioned or suspected of wrong things by the followers (see Rukwati 2012). They reject a form of structure and organisational hierarchy. They perceive structure as a form of impediment of their churches. In a meeting hosted at the Rhema bible church in Randburg, the Commission for the Promotion and Protection of the Rights of Cultural, Religious and Linguistic Communities (CRL) commission suggested that churches should have a peer review mechanism in order to deal with the current abuse of religion by various NPCs pastors (Koko 2019). Many of the pastors present that day rejected such a suggestion by the CRL commission; they saw it as a way of interference by the government on the freedom of religion. Thus, pastors do not want to account to anyone; hence, they are opposed to organisational culture. Therefore, anti-organisational culture can breed lack of accountability. It's sad because the pastor in this instance becomes the sole leader of the movement and control the day-to-day running of the church including the finances of the church. The only person he is accountable to is his wife who at many times is also the signatory of the church accounts. Thus, the church is run as a family business.

Pastors in NPCs refute human authority above their heads because they want to rely on the Holy Spirit as their central authority in their ministries. In this way, they can misuse the finances of the church and claim that they have heard from the Holy Spirit. Other than their reliance on the Holy Spirit, the main challenge is their theology of the position and authority of the pastor. The other big problem with accountability is the registration of churches. Some churches are registered as non-profit organisation (NPO), some as nongovernment organisation (NGO) and others as public benefit organisation (PBO). Some pastors go to an extreme of registering a church as personal business and they are the main authority on the account of the church. This is not the case in, for example, classical Pentecostal churches that are properly registered in South Africa. In this last category of registration, accountability is almost impossible, as the pastor's word is the final word. It is surprising because the early church in the book of Acts 15 had 'a Jerusalem council', whereby Apostles and elders discussed matters together in order to make informed decisions. Elsewhere according to Ogunewu and Adesegun (2011:5), the bible speaks of stewardship and the need for faithfulness (Lk 16:10) and seeking the kingdom other than material accumulation (Mt 6:33). It is not so in some of NPCs, and there is no council. As long as the pastor hears from God, there is no one who will question him or his actions. Anyone who is bold enough to question the man of God will be considered an opponent of the work of God. Instead of opposing the man or woman of God, there is dependence on them as 'baba', 'daddy', or 
'papa' to mediate between the believers and God (Maxwell 2006:142). Marshall (2009) adds that to be a follower of these prophets in Africa means to be aware of the power of God operating in men and women of God. It is this stature around men and women of God that make them unquestionable. Most of them have the propensity of telling the members of the church that they were not there when God called them into the ministry and therefore they do not have the authority to question the leader. Thus, the pastor becomes the only person who hears from God and the members should just obey. This is the crux of the problem in these mushrooming NPCs (Sande 2018:7).

The point in this article is that lack of accountability is caused by the lack of organisational culture. There is no organisational hierarchy in many NPCs where the pastor can report and be accountable to when it comes to finances and other important matters. Such a structure will also help the church as an organisation to raise finances outside themselves. Companies out there that are willing to donate large sums of money cannot do so to some churches because they lack structure. However, accountability should be demanded not only to attract donors but also because it is the right ministerial thing to do. But many churches and their pastors do not even report to the revenue services in their countries whilst there is proof that they make a lot of money. Pastors in NPCs cannot be accountable as they are driven by their ego and what they can make out of the people. Sometimes NPC leaders become obedient only to avoid negative consequences or when they want to serve self-interest or even when they have to gain something. Other than that they will remain domineering leaders who manipulate their congregants. It must be noted that accountability is important because these pastors serve as role models to the community and people look up to them (see Jentile 2016:37).

\section{Lack of financial stewardship}

Many pastors amongst NPCs are running the finances of the church, and the church as an organisation end up lacking stability in finances. The man or woman of God who is the main signatory of the church account can decide to buy an expensive car with the finances of the church and no one will confront him or her on that, as they like to quote a scripture 'touch not the anointed one of God and do his prophets no harm'. In a way, the untouchable man of God is costing the church in a big way because the church runs at a deficit as the account is most of the time overwithdrawn. The abuse of money by NPC pastors epitomises a lack of financial stewardship. The result of lack of stewardship in finances is schisms in NPCs because the congregations lose trust on their pastor. In addition, Pastors can go to an extreme of manipulating the books of the church to deceive the congregants, so that they can end up believing the pastor. The congregants on the other hand have been so blind to believe whatever the pastor is presenting in front of them. Only to find that what they are presenting is misleading the church (Englund 2007:491). The pastors of NPCs who lack financial stability do not desire to live according to the scriptures because they do not account to anyone. Some of them only want to preach and present the gospel without modelling the same gospel. Church to them is not a holy ground and a place of fellowship but a place for the pastor to enrich themselves in material wealth like cars and houses (Ayuk 2002:199). The failure to account in finances by NPC leaders has become the main predicament in Pentecostalism (Ukah 2007:626).

\section{Lack of clear vision}

When one lacks accountability, then one will ultimately lack clear vision. There is no proper vision. Yes, people are singing, clapping, dancing, rejoicing and shouting but the main question remains, where will these jubilant actions take us? The Proverbs 29:18 says 'where there is no vision the people perish'. Maybe this is one reason why so many NPC pastors abuse religion because they lack clear vision. This is seen even in the lack of thorough preparations in their sermons. Such messages are empty and do not even fulfil the great commission, which is the biggest vision of any ministry. The members in these congregations need to ask the bold question where the man of God is taking us to because without that vision there will always be chaos. However, men and women of God can never have a proper vision without embracing a proper structure and organisational hierarchy. This is because vision is not only embedded in words but in actions as well. This also brings me to the last point. Köhrsen (2015:2) points out that NPCs do have the ability to attract people with daily challenges who are seeking solution for their lives in hardships such as disease and health deficiencies, abuse, family trouble, alcoholism, drug dependency, poverty, unemployment, lack of clear vision in one's life and depression. However, the challenges in NPCs remain the lack of clear vision. For example, when such people receive their solutions, they return to their former churches or move to another Pentecostal church.

\section{Lack of stability}

The rejection to structure and organisational culture leads one to a form of instability. Hence, NPCs start but they do not go anywhere. Today they are here but tomorrow they are nowhere to be found. There is no legacy and succession plan. In most NPCs when the main pastor passes away, it marks the end of the ministry because there was no plan to keep the legacy of the main leader. Other than a structural issue the main challenge is that NPCs are based on the spiritual power of their founders, so when such a leader passes on, there is instability. In some instances, infightings happen amongst the siblings of the deceased. This unfortunately results in splits in the church. All of these problems are caused by a lack of structure and rejection of organisational culture by NPC pastors. It is for this reason that many pastors in NPCs cannot be trusted. On the other hand, a solid structure itself will bring about consistency in ministry that will not only exist in the present but will last for generations to come. The pastor might benefit in the present time by controlling all the finances of the church but having a proper structure will ensure that the coming generations benefit and 
not only the pastor and his or her family but the community at large. Ayuk (2002:198) opines that the lack of clear vision is caused by the fact that many churches have been founded by pastors without theological training. Therefore, they lack vision in terms of doctrines and the church administration. Luther and Finger (2016:12) add that anyone who insist in following Jesus without proper institution like the church is more likely to run into a lack of vision. Hence, a call to embrace a view of the church as institutional, even hierarchical, that is free of the lack of vision.

\section{The balance act between New Prophetic Churches and organisational culture}

This article images the possibility of having a balance between the emergence of NPCs and organisational culture that will be sustainable and inclusive. The reason is that without good organisational culture/systems, the growth of NPCs in South Africa is not maintainable. Hence, we have seen churches in South Africa open and close as they lack structure and proper governance. New Prophetic Church pastors run a risk of lacking accountability, financial stewardship, vision and stability. The second reason for this balance is that institution alone without the Spirit is equally disadvantageous. The argument is that churches that started well as movement later became stagnant whey they were institutionalised. Some were engaged in schisms because of organisational challenges. In the same way, the lack of a viable institutional culture is equally condemned for reasons highlighted above. The only way is to strike a balance between the growth of Pentecostalism and organisational culture. This is a possibility of allowing organisational culture without compromising the potential of growth in the church. In other words, the structure of the church must not be allowed to reign supreme over what God is doing in the church through his spirit. In the words of Synan and Yong (2017:11), Pentecostalism is not a static phenomenon, nor is it a phenomenon that can exist without some forms of empowering institutionalisation. Vondey (2012:125) adds that a high demand for institutionalisation and institution-building characterises the modern day Pentecostal movement. The unprecedented expansion of the movement across the world, the growth of membership and the lack of organisational structures at the original revivals soon demanded a higher degree of organisational leadership. Therefore, there is a need to find a grey area between growth and organisational culture.

The balancing act is an action or activity that requires a delicate balance between different situations or requirements. The balancing act between the NPCs and organisational culture is possible when the administration complements the operation of the church. In this way, the Holy Spirit should never be seen as a substitute for the administration of the church but as an agent that enables such administration (1 Cor 12:28). The works of the Holy Spirit and administration should complement each other. Kretzschmar (2008:65) that there should be interconnectedness between spirituality and administration. As much as the Holy Spirit plays a vital role in leading the operation of the church like in worship, ministration, preaching and other works, the same should happen for administration. It is clear that one of the requirements to serve the widows in Acts 6:1-7 was the infilling of the Holy Spirit (Ac 6:1-7). Thus, the Holy Spirit plays the role not only of teacher, guider and leader as stipulated in John 14:26 but also of administration. It is acknowledged here that the pastors cannot do both administration and ministry alone, they will need to appoint helpers to assist them in administration. When following the ministry of Jesus closely in Mark 6:30-44, one observes that His ministry had a spiritual wing and an administrative wing. The disciples of Jesus were responsible to administrate whatever Jesus wanted to happen in His ministry like distributing food and ushering the people. Jesus concentrated on praying for people in healing, deliverance and performance of other miracles. This model can work well in NPCs, that is, having people filled with the Holy Spirit to assist in administration whilst pastors continue with the ministration like teaching, preaching, counselling and so forth.

Second, perceiving hierarchy as a form of support and not hindrance. Although hierarchy can, and often does, hinder ministerial work, it is not its main function. The understanding is that hierarchy exists for the purpose of ensuring accountability to one another. The main purpose of having someone above the specific leader is not to hinder that leader but for the support of that leader. Thus, Pentecostals need to view structure not as an impediment to growth but as a resource for harnessing that growth. After all these structures exist elsewhere in society, so why not have them in the church. A family for example has a structure that consists of husband, the wife and the children supporting one another. In a similar way, the church must have a form of structure. Paul says that Jesus is the head of the church as the husband is the head of his own wife Eph 5:23. In some instances, Pentecostal pastors have become the centre and have removed Jesus as the head of the church. Jesus Christ is the head because he gives his life as a ransom for the redemption of the church. However, we need to understand Christ as the head of the corporate body, that is, the church in general terms. There should be heads of specific assemblies and such heads should have other people to oversee them in this regard.

Last, NPCs can learn to grow beyond the structure. The purpose of structure does not mean people are stuck with it. There are aspects of good structure like good governance, financial stewardship, church leadership and management that can enhance church growth. As much as there are aspects of bad structure like misuse of church funds, irresponsible and dishonest leadership hinder growth. So structure is not entirely negative, hence the researcher is aware of brothers and sisters in ministry who are within a certain structure but show some signs of growth within the same structures. There is a pastor in the Full Gospel denomination who has his own ministry in the denomination such that many people will 
come and gather for one of his annual meetings. The church structure has allowed him to grow within the system because ministry is not easy outside the system. Another example is a pastor in the AFM of South Africa who has also grown such that his Sunday services are broadcasted on television but did not have to leave the denomination to have such an impact on his ministry. This is opposed to many perceptions that young ministers have that says for one to grow, they have to be independent, which is not necessarily true. It is possible to grow within an established and well-organised structure and denomination.

\section{Conclusion}

A closer look at the spirit of anti-organisational culture reveals certain truth. Firstly, the spirit of anti-organisational culture has a potential to run the NPCs into a lack of accountability. Hence, in South Africa, for example, many ministers of the gospel are their own bosses without authority to report to and any motherly structure to oversee them. Secondly, the spirit of anti-organisational culture brings instability especially in the area of finances. Many NPC pastors are running the church finances by themselves. Consequently, the ministry is not stable and cannot maintain itself. When funds are not coming to the church, the pastor ends up engaging in wrongful acts in order to make ends meet. Thirdly, anti-organisational culture brings lack of vision whereby the church is growing but without a proper vision. This brings us to the last point, which is lack of stability. Hence, NPCs start and close at the same time. To help remedy this situation, there is a need to balance the act between NPCs and organisational culture. New Prophetic Churches need to move towards organisational culture without allowing it to hinder their growth. Thus, NPCs cannot be studied without considering the contribution of organisational culture in Pentecostalism.

\section{Acknowledgements}

The author would like to thank the Department of Christian Spirituality, Church History and Missiology for the support provided in conducting this research.

\section{Competing interests}

The author declared that no competing interests exist.

\section{Author's contributions}

This article is solely written by M.S.K.

\section{Ethical consideration}

Ethical clearance was issued by the University of South Africa, College of Human Sciences Research Ethics Review Committee (CREC reference number: 2019-CHS-90343018-Dept).

\section{Funding information}

This study was financially supported by the University of South Africa.

\section{Data availability statement}

Data sharing is not applicable to this article as no new data were created or analysed in this study.

\section{Disclaimer}

The views and opinions expressed in this article are those of the authors and do not necessarily reflect the official policy or position of any affiliated agency of the authors.

\section{References}

Anderson, A.H., 1992, Bazalwane: African Pentecostals in South Africa, University of South Africa, Pretoria.

Anderson, A.H., 2002, 'The newer Pentecostal and Charismatic churches: The shape of future Christianity in Africa?', Pneuma 24(2), 167-184. https://doi.org/10.1163/ 15700740260388027

Anderson, A.H., 2004, An introduction to Pentecostalism. Global Charismatic Christianity, Cambridge University Press, Cambridge.

Anderson, A.H., 2005, 'New African initiated pentecostalism and charismatics in South Africa', Journal of Religion in Africa 35(1), 66-92. https://doi.org/10.1163/ 1570066052995843

Anderson, A.H., 2013, To the ends of the earth: Pentecostalism and the transformation of world Christianity, Oxford University Press, Oxford.

Ayuk, A.A., 2002, 'The Pentecostal transformation of Nigerian church life', Asian Journal of Pentecostal Studies 5(2), 189-204.

Banda, C., 2020, 'Mediating God's relationality? A trinitarian perichoretic critique of (in African neo-Pentecostalism', HTS Teologiese Studies/Theological Studies 7(1), a5856. https://doi.org/10.4102/hts.v7611.5856 in complex social contexts, Wipf and Stock Publishers, Eugene, OR.

Chitando, E. \& Biri, K., 2016, 'Walter Magaya's Prophetic Healing and Deliverance (PHD) ministries and Pentecostalism in Zimbabwe: A preliminary study with particular reference to ecumenism', Studia Historiae Ecclesiasticae 42(2), 72-85. https://doi.org/10.17159/2412-4265/2016/829

Connors, R. \& Smith, T., 2011, Change the culture, change the game: The breakthrough strategy for energizing your organization and creating accountability for results, Penguin, New York, NY.

Dube, B., 2020, "'Go and prophesy in your own land": Foreign prophets and popularism in South Africa. Evoking the need of Jonathanic theology for peaceful resolution of difference', Religions 11(1), 42. https://doi.org/10.3390/rel11010042

Englund, H., 2007, 'Pentecostalism beyond belief: Trust and democracy in a Malawian Township', Africa 77(4), 477-499. https://doi.org/10.3366/afr.2007.77.4.477

Fahlgren, S. \& Idestrom, J., 2016, Ecclesiology in the trenches: Theory and method under construction, ISD LLC, Bristol.

Frahm-Arp, M., 2010, Professional women in South African Pentecostal charismatic churches, Brill, Leiden.

Jaichandran, R. \& Madhav, B.D., 2003, 'Pentecostal spirituality in a postmodern World', Asian Journal of Pentecostal Studies 6(1), 39-61.

Jentile, T., 2016, 'The moral formation, pastoral leadership and contemporary Pentecostal/Charismatic Churches in Soweto', Doctoral dissertation, University of the Free State, Bloemfontein.

Kalu, O., 2008, African Pentecostalism: An introduction, Oxford University Press, Oxford.

Kärkkäinen, V.M., 2007, 'Encountering Christ in the full gospel way: An incarnational Pentecostal spirituality', Journal of the European Pentecostal Theological Association 27(1), 5-19. https://doi.org/10.1179/jeb.2007.27.1.002

Kay, W.K., 2011, Pentecostalism: A very short introduction, vol. 255, Oxford University Press, Oxford.

Kgatle, M.S., 2016, 'Sociological and theological factors that caused schisms in the Apostolic Faith Mission of South Africa', Studia Historiae Ecclesiasticae 42(1) Apostolic Faith Mission of South Africa, Studia
1-15. https://doi.org/10.25159/2412-4265/1216

Kgatle, M.S., 2017, 'A socio-historical analysis of the sections in the Apostolic Faith Mission of South Africa from 1908 to the present', Verbum et Ecclesia 38(1), 1-10. https://doi.org/10.4102/ve.v38i1.1668

Kgatle, M.S., 2019b, 'Reimagining the practice of Pentecostal prophecy in Southern Africa: A critical engagement', HTS Teologiese Studies/Theological Studies 75(4), 1-8. https://doi.org/10.4102/hts.v75i4.5183

Kgatle, M.S., 2019a, The fourth Pentecostal wave in South Africa: A critical engagement, Routledge, Abingdon.

Kgatle, M.S., 2020, 'New paradigms of pneumatological ecclesiology brought about by new prophetic churches within South African Pentecostalism', Verbum et Ecclesia 41(1), a2053. https://doi.org/10.4102/ve.v41i1.2053

Köhrsen, J., 2015, 'Pentecostal improvement strategies: A comparative reading on African and South American Pentecostalism', pp. 49-64, viewed 10 June 2015 from https://edoc.unibas.ch/38937/.

Koko, K., 2019, 'Churches are making headlines for all the wrong reasons', viewed 14 February 2019, from https://www.iol.co.za/the-star/news/churches-aremaking-headlines-for-all-the-wrong-reasons-19295744. 
Kretzschmar, L., 2008, 'Christian spirituality in dialogue with secular and African spiritualities with reference to moral formation and agency', Theological Viatorum 32(1), 63-95.

Luther, M. \& Finger, T.N., 2016, 'Pastoral reflections on Mennonite and Pentecostal sacramental spirituality', Presented to the Church of God/Mennonite Church USA Dialogue, October 17-18, 2016, Lee University School of Religion, Cleveland, TN.

Marshall, R., 2009, Political spiritualities: The Pentecostal revolution in Nigeria, University of Chicago Press, Chicago, IL.

Mashau, T.D., 2013, 'Ministering effectively in the context of Pentecostalism in Africa: A reformed missional reflection', In die Skriflig 47(1), 10-17. https://doi.org/ 10.4102/ids.v47i1.84

Maxwell, D., 2006, African gifts of the spirit: Pentecostalism \& the rise of a Zimbabwean transnational religious movement, James Currey, Athens.

Nel, M., 2019, African Pentecostalism and eschatological expectations: He is coming back again!, Cambridge Scholars Publishing, Newcastle.

Ogunewu, M.A. \& Adesegun, A., 2011, 'Biblical teachings on accountability: A challenge to Christian politicians and public office-holders', Asia-Africa Journal of Mission and Ministry (AAMM) 4(1), 27-38.

Omenyo, C.N. \& Arthur, W.A., 2013, 'The Bible says! Neo-prophetic hermeneutics in Africa', Studies in World Christianity 19(1), 50-70. https://doi.org/10.3366/swc. 2013.0038

Quayesi-Amakye, J., 2015, 'Prophetism in Ghana's new prophetic churches', Journal of the European Pentecostal Theological Association 35(2), 162-173. https://doi.org $/ 10.1179 / 18124461152.00000000019$
Ramantswana, H., 2019, 'Prophets praying for, or preying on people's faith: A reflection on prophetic ministry in the South African context', In die Skriflig/In Luce Verbi 53(4), 8. https://doi.org/10.4102/ids.v53i4.2495

Resane, K.T., 2017, "'And they shall make you eat grass like oxen" (Daniel 4:24): Reflections on recent practices in some New Charismatic Churches', Pharos Journal of Theology 98(1), 1-17.

Rukwati, T., 2012, 'Prophets mustn't be questioned', viewed 10 July 2012, from http:// www.herald.co.zw/prophets-mustnt-be-questioned.

Sande, N., 2018, 'Contextualising the theology of competition: Towards the nexus of pentecostal faith, politics and development in Zimbabwe', Afro Asian Journal of Social Sciences 8(3), 1-16.

Synan, V. \& Yong, A. (eds.), 2017, Global renewal Christianity: Spirit-empowered movements past, present, and future, vol. 4, Charisma Media, Lake Mary, FL.

Tsekpoe, C., 2019, 'Contemporary prophetic and deliverance ministry challenges in Africa', Transformation 36(4), 280-291. https://doi.org/10.1177/026537881 9866217

Ukah, A., 2007, 'Piety and profit: Accounting for money in West African Pentecostalism (Part 1)', Stellenbosch Theological Journal 48(3-4), 621-632.

Vengeyi, O., 2014, 'Zimbabwean Pentecostal prophets: Rekindling the "true and false prophecy"', in E Chitando, M.R Gunda \& J Kügler (eds), Debate Prophets, profits and the Bible in Zimbabwe, pp. 29-54, University of Bamberg Press, Bamberg.

Vondey, W., 2012, Pentecostalism: A guide for the perplexed, A\&C Black, London. 